\title{
Cell-Surface $\beta$-Amyloid Precursor Protein Stimulates Neurite Outgrowth of Hippocampal Neurons in an Isoform-Dependent Manner
}

\author{
Wei Qiao Qiu, Adriana Ferreira, Christine Miller, Edward H. Koo, and Dennis J. Selkoe \\ Department of Neurology and Program in Neuroscience, Harvard Medical School, and Center for Neurologic \\ Diseases, Department of Medicine (Neurology), Brigham and Women's Hospital, Boston, Massachusetts 02115
}

$\beta$-Amyloid precursor protein ( $\beta$ APP) is an integral membrane polypeptide expressed in many neural and non-neural cells. $\beta$ APP occurs in part at the cell surface and undergoes proteolytic processing to release the large soluble ectodomain $\left(A P P_{s}\right)$ and the amyloid $\beta$-peptide $(A \beta)$, both of which have apparent trophic activity in vitro. Despite intense interest in $\beta$ APP expression and metabolism, there is limited knowledge about the function mediated by $\beta$ APP inserted at the cell-surface. We established a coculture system in which BAPP-transfected $\mathrm{CHO}$ cells serve as a substrate for the growth of primary rat hippocampal neurons. Compared to nontransfected $\mathrm{CHO}$ cells, the increased surface $\beta A P P$ of the transfectants stimulated short-term neuronal adhesion and longer-term neurite outgrowth, whereas the increased amount of secreted APP, and $A \beta$ in conditioned medium produced no such effects when neurons were grown either on untransfected $\mathrm{CHO}$ cells or on a polylysine substrate. Moreover, a peptide which has been shown to block the trophic effects of secreted APP (Ninomiya et al., 1993) failed to interrupt the neurite promoting activity mediated by the surface-expressed $\beta$ APP. Surface-expressed $\beta A P_{751}$ or $\beta_{A P P_{770}}$ isoforms mediated more neurite outgrowth than did the $\beta_{A P P_{695}}$ isoform. Antibody blocking and regional deletion experiments indicated that the mid-region of the $\beta A P P$ ectodomain (residues 361-648) is involved in promoting neurite outgrowth. We conclude that surface-expressed celluIar $\beta$ APP has a neurite-promoting function which is distinct from the trophic function of the secreted $\beta$ APP derivatives and may have special significance during brain development.

[Key words: surface-expressed $\beta$-amyloid precursor protein (BAPP), CHO cells, hippocampal neurons, adhesion, neurite outgrowth]

\footnotetext{
Received Feb. 22, 1994; revised July 26, 1994; accepted Sept. 19, 1994.

We thank K. Kosik for the polyclonal DJ antibodies and helpful discussion, T. Saitoh and D. A. C. Otero for kindly providing the three synthetic $\beta$ APP peptides and sharing their unpublished data, and $\mathrm{S}$. Sisodia for supplying $\mathrm{APP}_{695}, \mathrm{APP}_{770}$, and $\mathrm{APP}_{770 \text { del }}$ CHO cells. We are grateful to A. Y. Hung, $\mathrm{M}$. Citron, and $\mathrm{C}$. Haass for suggestions and to N. Boucher for preparing the manuscript. This work was supported by NIH Grants AG06173 and AG07911 (LEAD Award) and the Foundation for Neurologic Diseases.

Correspondence should be addressed to Dennis J. Selkoe, M.D., Brigham and Women's Hospital, 221 Longwood Avenue, LMRC 103, Boston, MA 02115.

Copyright $\odot 1995$ Society for Neuroscience $0270-6474 / 95 / 152157-11 \$ 05.00 / 0$
}

Like many adhesion molecules of the cell surface, the $\beta$-amyloid precursor protein $(\beta \mathrm{APP})$ is an integral membrane polypeptide containing a large extracellular domain, a single transmembrane region and a short cytoplasmic tail (Kang et al., 1987). Because proteolytic processing of $\beta$ APP generates the amyloid $\beta$-peptide $(A \beta)$, the major component of the cerebral amyloid progressively deposited in Alzheimer's disease (Glenner and Wong, 1984), much effort is being directed at understanding the role of $\beta$ APP metabolism in the pathogenesis of this complex disorder. Two $\beta A P P$ processing pathways-secretory cleavage at or near the cell surface (Esch et al., 1990; Sisodia et al., 1990) and reinternalization and lysosomal targeting (Cole et al., 1989; Golde et al., 1992; Haass et al., 1992a)-have heen identified to date. Although both of these pathways regulate the amount of intact $\beta A P P$ at the cell surface, little is known about the normal function of surface $\beta$ APP, particularly in the CNS where $\beta A P P$ is expressed at highest abundance.

The $\beta$ APP pre-mRNA undergoes alternative exon splicing to yield three major isoforms of 695,751 , or 770 amino acids (Kang et al., 1987; Kitaguchi et al., 1988; Ponte et al., 1988; Tanzi et al., 1988). Two of these $\left(\beta A P_{751}\right.$ and $\left.\beta A P P_{770}\right)$ contain a 56 residue insert which is highly homologous to the Kunitz family of serine protease inhibitors (KPI) and are expressed ubiquitously. In contrast, the shorter isoform lacking the KPI motif, $\beta_{A P P}{ }_{695}$, is almost solely expressed in the nervous system, both in neurons (Tanzi et al., 1987; Neve et al., 1988) and glial cells (Haass et al., 1991). Although the functional role of $\mathrm{BAPP}_{695}$ is not clear, its expression is developmentally regulated during the differentiation of hippocampal neurons and neuronallike cell lines in vitro (Fukuchi et al., 1992; Hung et al., 1992). In addition, the expression of $\beta A P P$ is increased during cerebral genesis in vivo (Loffler and Huber, 1992; Masliah et al., 1992). Despite their high expression of $\beta A P P$, fetal neurons, astrocytes, and microglia show little secretory processing of the precursor into its soluble derivative $\left(\mathrm{APP}_{\mathrm{s}}\right.$ ) (Haass et al., 1991; Hung et al., 1992), implying that the cellular holoprotein, including that at the cell surface, plays the principal functional role during CNS development.

Secreted $\mathrm{APP}_{\mathrm{s}}$ has been shown to have trophic effects on cultured fibroblasts and to promote process outgrowth from neuronal-like cells (Saitoh et al., 1989; Schubert et al., 1989; Chen and Yankner, 1991; Milward et al., 1992). Biochemical studies indicate that $\mathrm{APP}_{s}$ can bind to sulfated proteoglycans, suggesting that the trophic effects of secreted $\mathrm{APP}_{\mathrm{s}}$ may be mediated by its adhesion to the extracellular matrix (Schubert et al., 1989; Narindrasorasak et al., 1991; Shioi et al., 1992; Small et al., 1994). 
Both soluble and membrane-associated human brain $\beta$ APP have been reported to increase neurite length and branching in PC12 cells (Milward et al., 1992). Furthermore, neurite outgrowth from neuroblastoma cells grown on collagen could be blocked by an antibody to BAPP, and cell-cell contact was also impaired by this antibody (Breen et al., 1991).

These various results raise the question of whether surfaceexpressed $\beta$ APP has a specific functional activity for developing neurons in addition to its role in generating APPs and other secreted products. If so, do secreted $\mathrm{APP}_{\mathrm{s}}$ and surface-expressed $\beta A P P$ promote neurite outgrowth through the same or different mechanisms? To investigate the function of cell-surface $\beta A P P$ in the nervous system and examine differences between its mode of action and that of $\mathrm{APP}_{s}$, we established a coculture system in which primary rat fetal hippocampal neurons are grown on monolayers of transfected $\mathrm{CHO}$ cells expressing different isoforms of $\beta A P P$ on their surfaces. To compare the effects of surface $\beta A P P$ to those of the secreted derivatives, neurons were also grown on either untransfected CHO cells or a poly-D-lysine substrate, each of which was supplemented with conditioned medium from $\beta$ APP-transfected cells. The results demonstrate that neurite outgrowth from hippocampal neurons in this culture system is promoted by increased surface-expressed $\beta$ APP but not by increased $\mathrm{APP}_{\mathrm{s}}$ and other secreted derivatives in the medium. In addition, surface-expressed $\beta$ APP isoforms containing the KPI domain (but not their $\mathrm{APP}_{\mathrm{s}}$ derivatives) promote neurite outgrowth more vigorously than does $\beta_{\mathrm{APP}}{ }_{695}$ in this system. Further, we define a region of the $\beta A P P$ ectodomain which mediates in part the cell adhesion/neurite-promoting function of surface $\beta$ APP.

\section{Materials and Methods}

CHO cell culture and DNA transfection. Chinese hamster ovary (CHO) cells were cultured in Dulbecco's modified Eagle's medium (DMEM) containing $10 \%$ fetal bovine serum (FBS), $2 \mathrm{~mm}$ glutamine, and antibiotics (complete medium). BAPP cDNAs were construeted into the $\mathrm{pRC/CMV}$ or $\mathrm{pSV}$ vectors, in which expression is under the control of cytomegalovirus promoter or SV40 enhancer/promoter, respectively. Single colonies of stable transfectants obtained by using lipofectin (GIBCO, Bethesda Research Labs) as described by the manufacturer were selected in G418 medium $(400 \mu \mathrm{g} / \mathrm{ml})$ and cloned.

Metabolic labeling, immunoprecipitation, and surface $\beta A P P$ assay. For metabolic labeling, confluent monolayers of $\mathrm{CHO}$ cells were preincubated for $15 \mathrm{~min}$ in medium without methionine (GIBCO) containing $1 \%$ FBS. The cells were then labeled for $2 \mathrm{hr}$ in the presence of 300 $\mu \mathrm{Ci}$ of ${ }^{35} \mathrm{~S}$-methionine, washed, and harvested. NP-40 detergent extracts of the labeled cells and culture supernatants were then analyzed by immunoprecipitation with various antibodies to $\beta A P P$, as previously described (Haass et al., 1991).

For the surface $\beta A P P$ binding assay, a $\beta A P P$ monoclonal antibody, $5 \mathrm{~A} 3$, which recognizes the mid-region of the $\beta A P P$ ectodomain, was used to quantitate the amount of surface-expressed precursor (Koo et al., 1993). Briefly, $1 \times 10^{5}$ CHO cells were seeded into 12 well plates. After $48 \mathrm{hr}$, the cells were extensively washed to remove all but trace amount of $\mathrm{APP}_{\mathrm{s}}$ that might be associated with the cell surface. Then the cells were chilled on ice and incubated with binding medium consisting of RPMI 1640 medium supplemented with $0.2 \%$ BSA. 5A3 was radioiodinated with Iodobeads (Pierce) to approximately $2-3 \mu \mathrm{Ci} / \mu \mathrm{g}$ protein and used at $10 \mathrm{~nm}$ per well. The cells were incubated with the labeled antibody for $1 \mathrm{hr}$ at $4^{\circ} \mathrm{C}$ and then washed five times with cold PBS over $30 \mathrm{~min}$. The cells were subsequently lysed with $0.2 \mathrm{M} \mathrm{NaOH}$, and radioactivity (cpm) was determined with a gamma counter. All samples were assayed in triplicate and the results expressed as average \pm SEM.

Adhesion assays. Primary neurons were prepared from the dissected hippocampi of embryonic day 19 rats as previously described (Bartlett and Banker, 1984; Goslin and Banker, 1991). To assay CHO and liippocampal neuron cell-cell adhesion, $1.5 \times 10^{5}$ dissociated rat fetal hip- pocampal neurons in $3 \mathrm{ml}$ of complete medium with $10 \%$ FBS were plated in $60 \mathrm{~mm}$ tissue culture dishes onto confluent monolayers of $\beta A P P-t r a n s f e c t e d$ and untransfected $\mathrm{CHO}$ cells which had been washed three times with complete medium. After incubation at $37^{\circ} \mathrm{C}$ for the indicated times, the plates were swirled and washed three times. The unattached neurons were collected and counted by hemocytometer; the same procedure performed on the CHO cultures alone (without neurons) yielded virtually no unattached cells. This result was confirmed by directly counting the attached neurons in 10 randomly chosen fields, based on the morphological differences between neurons and $\mathrm{CHO}$ cells. $\Lambda \mathrm{t}$ each time point, each cell type had triplet samples assayed, and each experiment was repeated three times.

Neurite outgrowth assay. Approximately $6 \times 10^{5}$ untransfected on $\beta A P P$-transfected CHO cells were seeded in $60 \mathrm{~mm}$ tissue culture plates and grown for about $36 \mathrm{hr}$ in complete DMEM medium until reaching approximately $80 \%$ confluence. For coculture experiments, the hippocampal neurons were plated at a density of 100,000 cells per $60 \mathrm{~mm}$ petri dish on glass coverslips that were covered with monolayers of $\mathrm{CHO}$ cells. In the experiments analyzing different conditioned media, the same number of neurons was plated on glass coverslips coated with poly-D-lysine $(1 \mathrm{mg} / \mathrm{ml})$. The neurons were grown in a $1: 1$ mixture of DMEM and Ham's F12 medium supplemented with $10 \%$ FBS, 600 $\mathrm{mg} \%$ glucose, $1 \mathrm{~mm}$ pyruvate, $2 \mathrm{~mm}$ glutamine, and the $\mathrm{N} 2$ supplements (complete medium) (Bottenstein and Sato, 1979) and maintained at $37^{\circ} \mathrm{C}$ with $5 \% \mathrm{CO}_{2}$. Two to four hours later, the medium was changed to medium without FBS.

After incubation at $37^{\circ} \mathrm{C}$ for $26-28 \mathrm{hr}$, the coverslips were gently rinsed in PBS and fixed with $4 \%$ paraformaldehyde. The fixed cells were reacted with polyclonal antiserum DJ (Kosik et al., 1988) to human microtubule-associated proteins (principally tau and MAP2), followed by biotin-conjugated goat anti-rabbit antibodies, ExtrAvidin peroxidase and reaction with DAB, as described by the manufacturer (Sigma). These proteins are specifically expressed in neurons (Kosik et al., 1988) and absent from CHO cells, and DJ was therefore used to visualize and quantitate neurites. Fixed cells were viewed through an inverted phase microscope using a video camera and images were projected onto the screen. Neurons were selected at random, traced from the screen, and the lengths of their processes measured using a digitizing tablet. The data from multiple neurons in a culture were pooled, and an estimate of the total neuritic length per cell was calculated as the ratio of the sum of the lengths of neurites over the number of cell bodies counted.

\section{Results}

Increased surface expression of $\beta A P P$ in $C H O$ cells enhances cell-cell adhesion

Four constructs encoding human $\beta_{A P P_{695}}, \beta_{A P P}{ }_{751}, \beta A P P_{770}$, or $\beta_{A P P_{770}}$ containing a deletion of residues $380-666\left[\beta A P P_{770 d e l}\right.$ (Wang et al., 1991)] (see Fig. 1A) were cloned into either the $\mathrm{pRC} / \mathrm{CMV}$ vector or $\mathrm{pSV}$ vector, in which expression is under the control of the cytomegalovirus promoter or the SV40 promoter, respectively. Following stable transfection into $\mathrm{CHO}$ cells, clones derived from single cells were obtained by selection in G418 medium.

Biochemical characterization of $\beta A P P$ and its secreted derivatives in the parent $\mathrm{CHO}$ cells and representative clones transfected with $\beta \mathrm{APP}_{695}, \beta \mathrm{APP} \mathrm{P}_{770}$, or $\beta \mathrm{APP}{ }_{770}$ del are shown in Figure 1 . To analyze the polypeptide forms of $\beta A P P$ expressed and metabolized by the CHO transfcctants, detergent extracts of metabolically labeled cells and their conditioned media were analyzed by immunoprecipitation with four antibodies recognizing different regions of $\beta$ APP. An antiserum (C7) (Haass et al., 1992a) to the conserved cytoplasmic domain of $\beta$ APP detected a doublet in all the lines which had the expected migration of the $\mathrm{N}$ - and $\mathrm{N}+\mathrm{O}$-glycosylated full-length proteins (Weidemann et al., 1989; Oltersdorf et al., 1990) (Fig. 1B). The parental CHO cells expressed endogenous $\beta A P_{751770}$, and the $\beta A P P_{770}$ del transfectants expressed the expected $65 \mathrm{kDa}$ and $70 \mathrm{kDa}$ truncated proteins (Fig. $1 B$ ). To characterize APPs, the principal se- 
A.

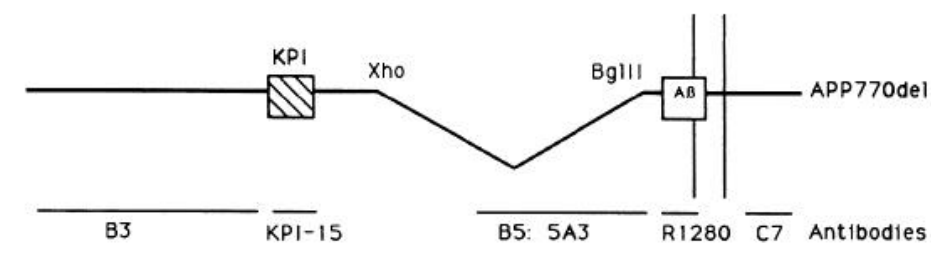

B.

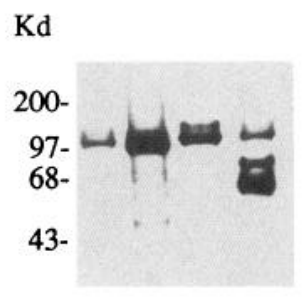

$\begin{array}{llll}1 & 2 & 3 & 4\end{array}$
C.

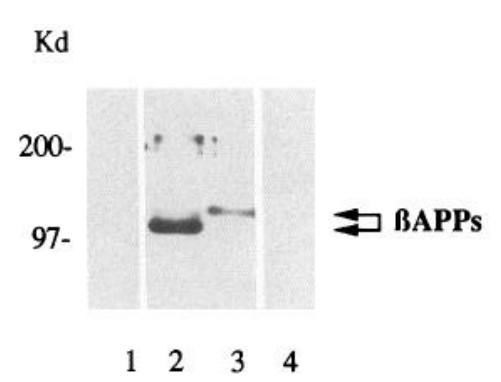

D.

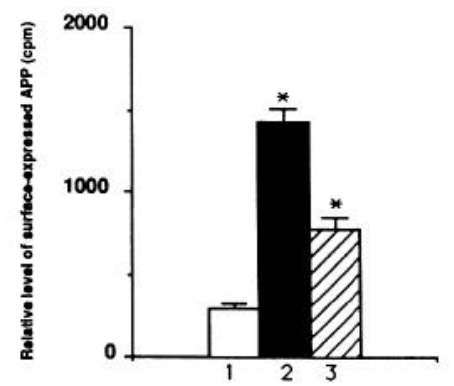

Figure 1. Biochemical analysis of the $\beta$-amyloid precursor protein and its surface expression by $\mathrm{CHO}$ transfectants. $A$, The structure of APP ${ }_{770}$ del is schematically presented. Vertical lines designate the single transmembrane domain of $\beta$ APP. The Kunitz protease inhibitor $(K P I)$ motif and the $\mathrm{A} \beta$ peptides are indicated. The regions of $\beta$ APP which were the immunogens for the antibodies used in this study are shown as horizontal lines under the schematic. $B$, Immunoprecipitates of $\beta$ APP holoproteins from cell lysates with an antiserum $(C 7)$ to the carboxyl terminus of the

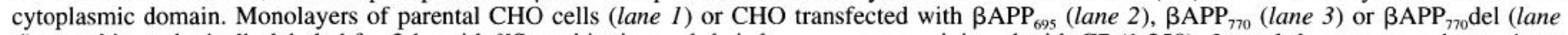
4 ) were biosynthetically labeled for $2 \mathrm{hr}$ with ${ }^{35} \mathrm{~S}$-methionine and their lysates were precipitated with $\mathrm{C} 7$ (1:250). Lane 1 demonstrates the predominant $\beta A P P_{751}$ isoform expressed endogenously by $\mathrm{CHO}$ cells. This form is again seen in lane 4 , together with the expected truncated forms of the precursor arising from the $\beta_{A P P} P_{770 d e l}$ construct. The characteristic $\mathrm{N}$ - and $\mathrm{N}+\mathrm{O}$-glycosylated species of $\beta$ APP (Weidemann et al., 1989 ; Oltersdorf et al., 1990) are only partially resolved in this $10-30 \%$ tricine gel. $C$, Immunoprecipitation of $\mathrm{APP}_{\mathrm{s}}$ in the conditioned media with a human-specific $\beta A P P$ antibody $(B 5)$ to recombinant $\beta A P_{519-666}\left(\beta A P P_{770}\right.$ numbering). Aliquots of the conditioned media from the same cells shown in $(B)$ were immunoprecipitated from plain $\mathrm{CHO}$ (lane 1 ) or $\beta \mathrm{APP}_{695}$ (lane 2), $\beta \mathrm{APP}_{770}$ (lane 3) or $\beta \mathrm{APP}_{770}$ del (lane 4 ) $\mathrm{CHO}_{\text {transfectants. Only } \beta \mathrm{APP}} \mathrm{O}_{695}$ and $\beta \mathrm{APP}_{770}$ produce $\mathrm{APP}_{\mathrm{s}}$ immunoprecipitable with this antibody, as expected. $D$, Quantitative analysis of surface-expressed $\beta \mathrm{APP}$ using the binding of ${ }^{125} \mathrm{I}$-labeled monoclonal antibody $5 \mathrm{~A} 3$, directed at an epitope of the mid-region ectodomain (see $A$ ). Plates of untransfected CHO (bar 1 ), or $\beta_{A P P_{695}}$ (bar 2) or $\beta \mathrm{APP}_{770}$ (bar 3) transfectants were seeded with equal numbers of cells, grown to confluence and incubated with the same amount of ${ }^{125}$ I-labeled $5 \mathrm{~A} 3$. The cells were washed three times and measured for bound 5A3. Bars represent means \pm SD of binding calculated from triplicate dishes in each of three independent experiments. Asterisks indicate significant increase $(p<0.05)$ of $5 \mathrm{~A} 3$ binding compared to that for untransfected $\mathrm{CHO}$ cells.

creted derivative of $\beta$ APP, a human-specific $\beta$ APP antibody (B5) (Oltersdorf et al., 1990; Haass et al., 1992a) was used to precipitate conditioned media (Fig. 1C). Because the parental $\mathrm{CHO}$ is a rodent-derived line and because the region recognized by $\mathrm{B} 5$ is deleted in $\mathrm{BAPP}_{770 \mathrm{del}}$, the soluble forms of these proteins are not precipitable by B5 (lanes 1 and 4 of Fig. $1 C$ ). In addition, an antiserum [(R1280) (Haass et al., 1992b)] directed against the $A \beta_{1-40}$ fragment of $\beta$ APP was used to immunoprecipitate the media. Soluble APP of the appropriate size expected from each construct as well as $\mathrm{A} \beta(4 \mathrm{kDa})$ and a related $3 \mathrm{kDa}$ fragment (p3) were all detected, in agreement with previous studies (Haass et al., 1992b; Seubert et al., 1992b; Shoji et al., 1992) (data not shown). $\beta \mathrm{APP}_{770 \mathrm{del}}$ cell line secreted a truncated $\mathrm{APP}_{\mathrm{s}}$ protein of the predicted size.

In order to examine how much $\beta$ APP holoprotein was expressed at the surface of transfected compared to untransfected $\mathrm{CHO}$ cells, an ${ }^{125}$ I-labeled monoclonal antibody, 5A3 (Koo et al., 1993), which recognizes an epitope in the extracellular do- main of both human and rodent $\beta$ APP (Fig. $1 A$ ), was incubated with confluent monolayers of each cell type. Because both light and electron microscopy has shown that $5 \mathrm{~A} 3$ reacts primarily with cell-surface $\beta \mathrm{APP}$ in these $\mathrm{CHO}$ cells (with subsequent rapid internalization of the antibody/ $\beta$ APP complex) while no $\mathrm{APP}_{\mathrm{s}}$ is detected on the matrix between cell bodies (T. Yamazaki, E. Koo, and D. J. Selkoe, unpublished data), this experiment reveals the relative expression level of $\beta$ APP on the cell surface but not the association of $\mathrm{APP}_{\mathrm{s}}$ with extracellular matrix. As shown in Figure $1 D$, the amount of surface-expressed $\beta A P_{695}$ is approximately five times that in parental CHO cells, whereas the $\beta \mathrm{APP}_{770} \mathrm{CHO}$ clone has an approximately 2.5 -fold increase in surface molecules. Taking all of the above results together, our transfected $\mathrm{CHO}$ cells produce variable amounts of surfaceinserted $\beta A P P$ and metabolize the $\beta A P P$ in the same pattern as described previously in other $\beta$ APP-expressing cells (Weidemann et al., 1989; Olterdorf, 1990; Haass et al., 1992b; Shoji et al., 1992). 
A.

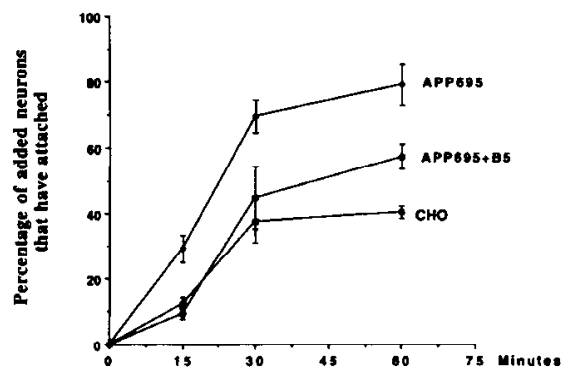

B.

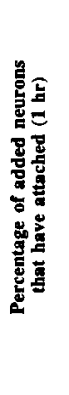

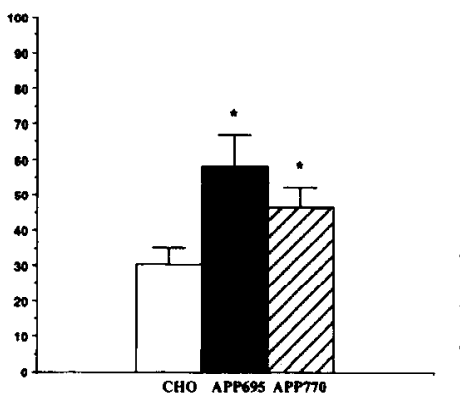

c.

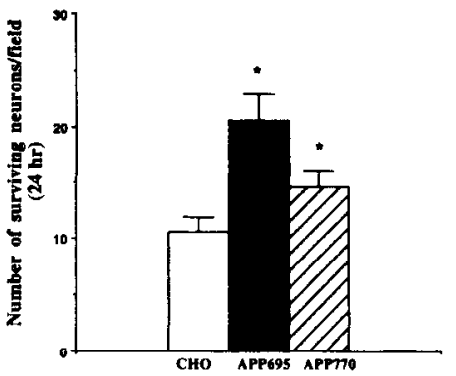

Figure 2. Enhanced short term adhesion of hippocampal neurons to $\beta A P P$-expressing CHO cells is accompanied by longer term survival. A, Kinetics of short-term adhesion. Dissociated rat fetal hippocampal neurons $\left(1.5 \times 10^{5}\right.$ cells $)$ in complete medium were plated on monolayers of untransfected or $\beta A P P_{695}$-transfected cells and incubated at $37^{\circ} \mathrm{C}$ in the presence or absence of antibody, B5. At each time point, the unattached neurons were collected and counted; attached neurons were also observed and counted after washing the cultures three times. Results are expressed as the percentage of neurons seeded at time zero that have attached. Values shown are the means \pm SEM of three independent experiments. $B$,

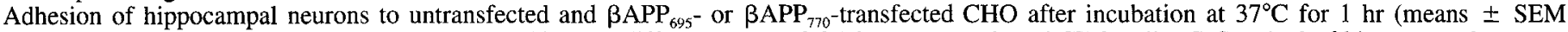
for four independent experiments). Asterisks, Significantly different at $p<0.05$ from untransfected CHO cells. $C$, Survival of hippocampal neurons grown on untransfected, $\beta \mathrm{APP}_{695}$ - or $\beta \mathrm{APP}_{770^{-}}$-transfected $\mathrm{CHO}$, as quantitated after coculturing for $26-28 \mathrm{hr}$ (means \pm SEM of surviving neurons in a total of 30 random microscopic fields obtained from three independent experiments). Asterisks indicate significant differences $(p<0.02)$ relative to the effect of untransfected $\mathrm{CHO}$ cells.

We next asked whether surface-expressed $\beta A P P$ could mediate cell-cell adhesion in neural cells. To observe cell-cell contact, monolayers of various $\beta$ APP-transfected $\mathrm{CHO}$ cell lines were used as a substrate for short-term adhesion assays of dissociated rat fetal hippocampal neurons. Equal numbers of dissociated neurons were plated on untransfected or transfected CHO cells and incubated at $37^{\circ} \mathrm{C}$ for various times, after which the cells were washed three times with complete medium and the unattached neurons were collected. The number of unattached neurons was counted, and the percentage of neurons that had attached was calculated. At the same time, the attached neurons were observed for their morphological characteristics and were counted from ten randomly chosen fields to confirm the attachment ratios among the different samples. As shown in Figure $2 A$, a reproducible and substantial increase in adhesiveness of hippocampal neurons to $\beta \mathrm{APP}_{695}$-transfected versus parental CHO cells was observed at 15,30 , and $60 \mathrm{~min}$. The adhesion mediated by the $\beta_{A P P_{695}}$ transfectant was attenuated by incubation with the human 3 APP-specific antibody, B5 (Fig. 2A). To support this finding, the same neuronal adhesion experiment was performed on a primary rat astrocyte monolayer instead of CHO cells and also demonstrated a significant $(p<0.025)$ inhibition of neuronal adhesion following the addition of B5 (data not shown). Consistent with the levels of surface-expressed $\beta A P P$ (Fig. $1 D$ ), the $\beta A P_{695}$ CHO transfectants had the highest number of attached neurons after one hour incubation, followed by $\beta \mathrm{APP}_{770}$ transfectants and then control CHO cells (Fig. $2 B$ ) (differences significant at $p<0.05$ ). Furthermore, the increase in short-term cell-cell adhesion on transfectants correlated well with the greater number of neurons present after $26-28 \mathrm{hr}$ coculturing (Fig. 2C) (differences significant at $p<0.02$ ). Therefore, our data suggest that the increased expression of cell-surface $\beta A P P$ confers new adhesive properties to the parental $\mathrm{CHO}$ cells that mediate enhanced cell-cell contact and cell retention.

\section{Cells expressing surface BAPP stimulate neurite extension of} hippocampal neurons in an isoform-dependent manner

To examine the potential function of cell-surface $\beta$ APP in neural development, we next investigated whether monolayers of various $\beta$ APP-transfected $\mathrm{CHO}$ cells would stimulate the extension of neurites when used as a substrate for growing dissociated rat fetal hippocampal neurons. Neurite outgrowth was quantitated after $26-28 \mathrm{hr}$ of cocultivation by fixing the cells and staining with an antiserum [DJ (Kosik et al., 1988)] which sensitively detects the neuron-specific microtubule-associated proteins, tau and MAP 2. CHO cells are not recognized by this antiserum.

In general, the morphology of neurons grown on monolayers of both control and transfected CHO cells was relatively simple, with approximately $90 \%$ of the cells having fewer than three primary processes (Fig. 3). However, marked differences were observed in the ability of the transfected and untransfected $\mathrm{CHO}$ cells to promote neurite outgrowth. As illustrated in Figure 3A$C$, neurons grown on $\beta$ APP-transfected cells characteristically showed long neurites extending from the cell bodies, in contrast to shorter processes that grew on control CHO monolayers. When neurite outgrowth was quantified by computer-assisted image analysis, the total neuritic length per cell on $\beta_{A P P}{ }_{695}-$ or $\beta A P P_{770}$-transfected cells was found to be about twofold higher than on parental $\mathrm{CHO}$ cells $(p<0.05)$ (Fig. $4 A)$. To exclude the possibility that this augmentation was due to an increase in neuronal density rather than to dircet stimulation of neurites by the $\beta$ APP-expressing transfectants, we plated double the number of hippocampal neurons on the untransfected $\mathrm{CHO}$ cells to obtain roughly equal numbers of surviving neurons at $26-28 \mathrm{hr}$; no increase of neurite outgrowth was observed (Fig. $4 B$ ). The number of primary neurites per cell did not differ between neurons grown on plain $\mathrm{CHO}$ or on the transfectants (Fig. $4 \mathrm{C}$ ), suggesting that $\beta$ APP can stimulate the growth of preexisting small processes but cannot initiate outgrowth of new neurites.

Although the level of surface expression of the $\beta_{A P P} P_{770}$ transfected clone was reproducibly found to be one-half that of the $\beta_{A P P_{695}}$ transfectants (Fig. $1 D$ ), the ability of these cell lines to stimulate neurite outgrowth was approximately the same (Fig. $4 A$ ). This finding suggests that the KPI domain in $\beta A P P_{770}$ may serve to additionally stimulate neurite growth. To confirm this apparent potentiation by $\beta_{\mathrm{APP}} \mathrm{P}_{71 / 770}$ isoforms, two $\beta \mathrm{APP}_{695}$ clones $\left(\beta A \mathrm{AP}_{695}\right.$ and $\left.\beta \mathrm{APP}_{695} \mathrm{~B} 4\right)$, two $\beta \mathrm{APP}_{751}$ clones $\left(\beta_{A P P}{ }_{751}-2\right.$ and $\left.\beta A P P_{751} \mathrm{D} 4\right)$, and one $\beta A P_{770}$ clone were compared as to level of $\beta$ APP surface expression and degree of neurite stimulation. As shown in Table 1 , the clones $\beta A P_{770}$, 

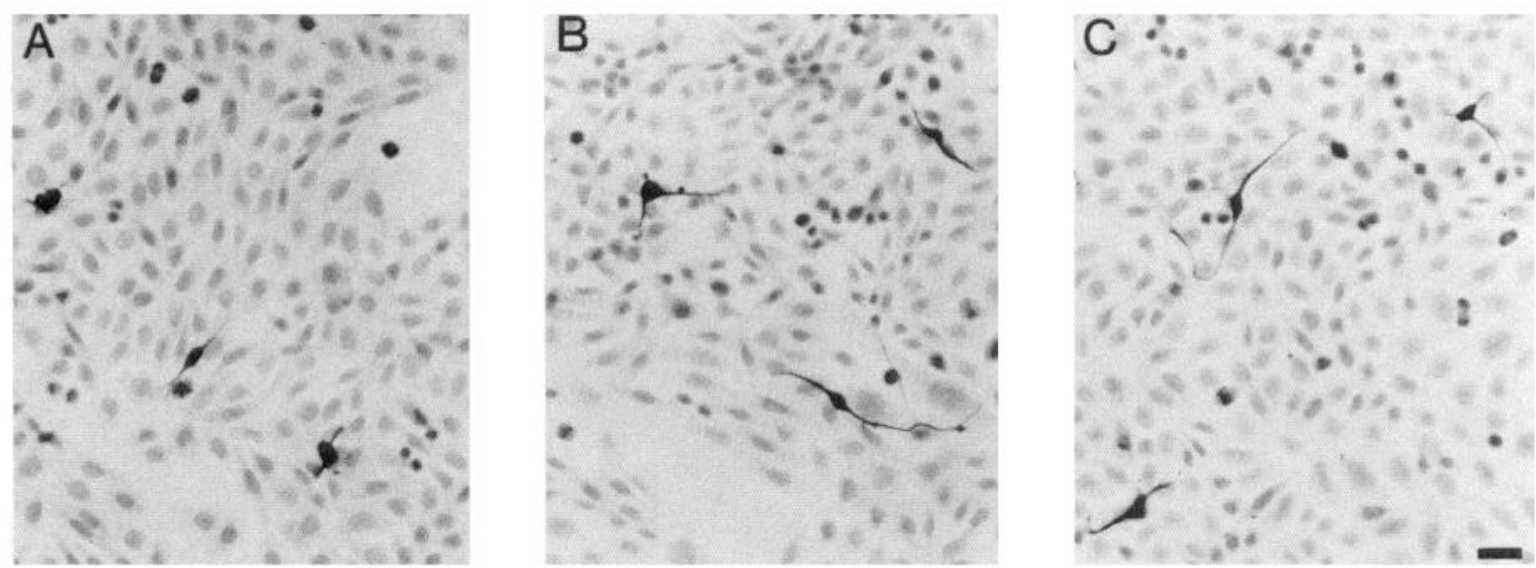

Figure 3. Hippocampal neurons cultured on $\beta_{A P P}{ }_{69}^{-}$and $\beta A P P_{770^{-}}$transfected $\mathrm{CHO}$ cells show enhanced neurite outgrowth. Representative photomicrographs of rat fetal day 19 hippocampal neurons were grown on monolayers of untransfected $\mathrm{CHO}$ cells $(A)$, or $\beta$ APP $695(B)$ or $\beta A P P_{770}$ $(C)$ transfectants. After $26-28 \mathrm{hr}$, the cultures were fixed and reacted with antiserum DJ to tau and MAP 2 proteins, which are specifically expressed in neurons, followed by sequential reactions with biotin-conjugated goat anti-rabbit antibodies, ExtrAvidin-peroxidase complex and DAB. Scale bar, $20 \mu \mathrm{m}$.

$\beta_{A P P}{ }_{751} \mathrm{D} 4$, and $\beta A P P_{695} \mathrm{~B} 4$ had highly similar levels of surfaceexpressed $\beta \mathrm{APP}$, but $\beta \mathrm{APP}_{770}$ and $\beta \mathrm{APP}_{751} \mathrm{D} 4$ constructs produced greater neurite outgrowth than $\beta_{\mathrm{APP}}{ }_{695} \mathrm{~B} 4$ did $(p<0.05)$. Moreover, although clone $\beta_{A P P_{751}}-2$ had less surface-expressed $\beta$ APP than clone $\beta \mathrm{APP}_{695} \beta 4$ did, it stimulated neurite outgrowth to the same or slightly greater degree. Following the addition of an antibody (KPI-15) to the KPI domain in order to block its activity, the ability of clone $\beta A P P_{770}$ to stimulate neurite outgrowth decreased significantly $(p<0.05)$ (Table 1$)$. As a control for this experiment, the KPI-15 antibody had no effect on the neurite-promoting activity of $\beta_{\mathrm{APP}}{ }_{695}$, as expected (Table 1). This experiment was repeated using a second KPI-specific antibody with similar results (data not shown). These data indicate that the degree of neurite stimulation in our system is dependent in part on the BAPP isoform expressed.

\section{Surface-expressed $\beta A P P$ promotes neurite outgrowth via a mechanism distinct from $A P P_{s}$}

The data presented above do not allow one to determine whether the neuronal adhesion and neurite outgrowth stimulated by the $\beta A P P$ transfectants are mediated by surface molecules or secreted derivatives of $\beta$ APP. To assess whether any trophic effects mediated by the increased amounts of $\mathrm{APP}_{\mathrm{s}}$ and $\mathrm{A} \beta$ released by the transfected $\mathrm{CHO}$ cells contributed to the results shown in Figure $4 A$, we grew the neurons on untransfected $\mathrm{CHO}$ cells supplemented with the overnight conditioned medium of the same $\beta_{A P P}{ }_{695}$ transfectants. No neurite promotion was observed compared to identical cultures grown without this supplement (Fig. 4B). This result argues strongly against a significant role for APPs on neurite outgrowth under our conditions, whether as a diffusible molecule or by an interaction between $\mathrm{APP}_{\mathrm{s}}$ and the extracellular matrix. To examine this question further, we used poly-D-lysine as a substrate to grow the hippocampal neurons under otherwise identical conditions in the conditioned media obtained from the same untransfected and transfected CHO cells. After 26-28 hr, no obvious morphological differences were observed among neurons cultured in the conditioned media of untransfected $\mathrm{CHO}, \beta_{\mathrm{APP}} \mathrm{P}_{65}$ or $\mathrm{BAPP}_{770}$ cells (Fig. $5 A-C$ ). Quantitation by image analysis confirmed the absence of detectable effects of the conditioned media of the transfectants on total neurite length per hippocampal neuron (Fig. 6A). Because the total neurite length/hippocampal neuron on the same poly-D-lysine substrate extends to $220 \mu \mathrm{m}$ in the presence of astroglial conditioned medium (Ferreira et al., 1992) but was only $160 \mu \mathrm{m}$

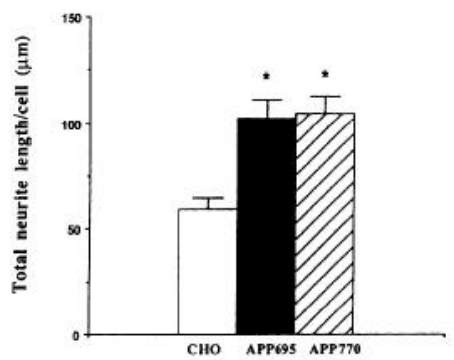

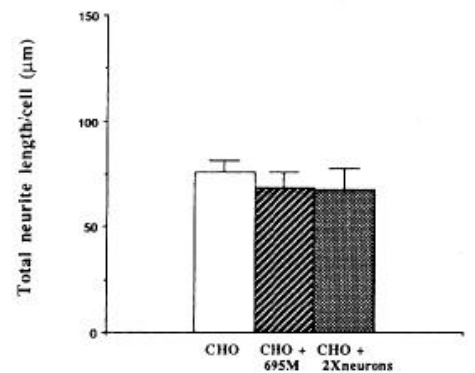

C.

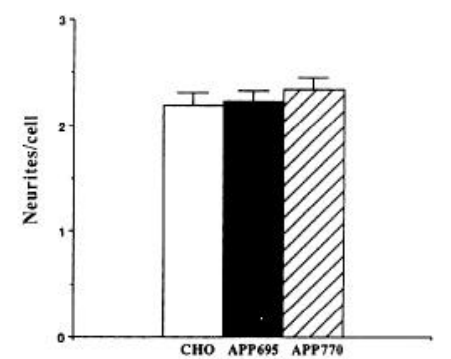

Figure 4. Quantitation of neurite length and number in hippocampal neurons cultured on CHO cells. $A$ and $C$, Total neurite length per cell ( $A$ ) and neurite number per cell $(C)$ under the same conditions described in Figure 3 were quantitated by computer-assisted image analysis. $B$, Total neurite length per cell of neurons which were grown on monolayers of untransfected $\mathrm{CHO}$ cells without $(\mathrm{CHO})$ or with $(\mathrm{CHO}+695 \mathrm{M})$ medium conditioned by $\beta_{A P P} 69$-transfected $\mathrm{CHO}$ or which were grown by plating twice the number of neurons as usual (CHO $+2 \mathrm{Xneurons}$ ). Neurite length was defined as the sum of the lengths of all branches extending from a given cell body. Data are expressed as means \pm SEM from a total of 70 neurons analyzed. Asterisks indicate significant differences $(p<0.05)$ relative to growth on plain CHO cells. 


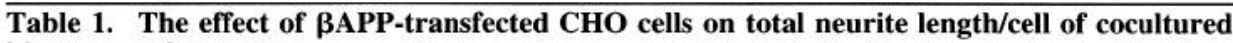
hippocampal neurons

\begin{tabular}{|c|c|c|c|c|}
\hline $\begin{array}{l}\text { Transfected } \\
\text { CHO clones } \\
\end{array}$ & $\begin{array}{l}\text { Surface-expressed } \\
\beta A P P \text { (cpm of } \\
\text { 125 5A3 binding) }\end{array}$ & $\begin{array}{l}\text { Total neurite } \\
\text { length/cell }(\mu \mathrm{m})\end{array}$ & $\begin{array}{l}\text { Total number of } \\
\text { neurons examined }\end{array}$ & $\begin{array}{l}\text { Number of } \\
\text { experiments }\end{array}$ \\
\hline $\mathrm{APP}_{695}$ & $1424 \pm 82$ & $103.7 \pm 8.7$ & 63 & 3 \\
\hline $\mathrm{APP}_{695}+\mathrm{KPI}-15$ & & $109.4 \pm 8.4$ & 69 & 3 \\
\hline $\mathrm{APP}_{695} \mathrm{~B} 4$ & $699 \pm 19$ & $77.1 \pm 6.0^{*}$ & 65 & 2 \\
\hline $\mathrm{APP}_{751}-2$ & $431 \pm 24$ & $84.0 \pm 7.9$ & 65 & 2 \\
\hline $\mathrm{APP}_{751} \mathrm{D} 4$ & $800 \pm 22$ & $113.2 \pm 10.5$ & 54 & 2 \\
\hline $\mathrm{APP}_{770}$ & $774 \pm 74$ & $95.1 \pm 7.9$ & 69 & 3 \\
\hline $\mathrm{APP}_{770}+\mathrm{KPI}-15$ & & $78.9 \pm 5.8^{* *}$ & 79 & 3 \\
\hline
\end{tabular}

in this experiment, the neurons grown on poly-D-lysine (Figs. $5 A, 6 A$ ) had not achieved their maximum possible neurite length. Therefore, because there is considerable endogenous $\beta$ APP production and $\mathrm{APP}_{\mathrm{s}}$ release in the parental $\mathrm{CHO}$ cells (Fig. 1), we propose that the lack of response by neurons to the increased $\mathrm{APP}_{\mathrm{s}}$ in the transfectant cocultures is due to the saturation of the neuronal cells by binding of the basal endogenous $\mathrm{APP}_{\mathrm{s}}$, rather than a complete lack of neurite-promoting activity of $\mathrm{APP}_{\mathrm{s}}$ on hippocampal neurons. As a further control to confirm these results, the conditioned medium from our $\beta_{A P P}{ }_{695}$ transfectants was added to cultures of PC12 cells similarly grown on poly-Dlysine. Here, the $\beta_{A P P}{ }_{695}$ conditioned medium caused a significant twofold increase in neurite outgrowth of $\mathrm{PC} 12$ cells compared to medium from untransfected $\mathrm{CHO}$ (Fig. 6B), indicating that the secreted $\mathrm{APP}_{\mathrm{s}}$ produced by our transfectants can indeed exert the trophic activity of this molecule that has been described previously (Milward et al., 1992).

Because a sequence of five amino acids, RERMS (residues 328-332 of $\beta \mathrm{APP}_{695}$ ) was found to confer this growth-promoting activity of $\mathrm{APP}_{\mathrm{s}}$ on fibroblasts and neuroblastoma cells (Ninomiya et al., 1993), an 11-mer synthetic peptide (amino acids 325-335 of $\beta_{A P P}{ }_{695}$ ) or a 17-mer peptide (amino acids 319-335 of $\left.\beta A P_{695}\right)$, each including the RERMS sequence, were added to hippocampal neuronal cultures grown on poly-D-lysine in the conditioned medium of untransfected $\mathrm{CHO}$ cells to confirm the apparent saturation effect of the endogenously produced APPs. Both peptide batches had previously been shown to promote growth of fibroblasts and neuroblastoma cells (T. Saitoh, personal communication). Again, no increase in total neurite length per hippocampal neuron was observed in our cultures, using concentrations of these trophic peptides ranging from $10 \mathrm{pm}$ to $100 \mathrm{~nm}$ (Fig. 6C).

The above data (Figs. $4 B, 6 A-C$ ) clearly indicate that the increased amounts of $\mathrm{APP}_{\mathrm{s}}$ and $\mathrm{A} \beta$ released into the conditioned media of our $\beta$ APP-transfected cells do not further stimulate neurite outgrowth from fetal hippocampal neurons when compared to the media of $\mathrm{CHO}$ expressing only endogenous $\beta$ APP. This finding strongly suggests that the neuronal attachment and neurite-promoting activities observed in our system (Figs. 3, 4) are mediated by surface-expressed $\beta$ APP rather than secreted $\mathrm{APP}_{\mathrm{s}}$. As a further test, we added the antagonist peptide ERMSQVM, which has been shown to block the growth-promoting activity of secreted $\mathrm{APP}_{\mathrm{s}}$ on fibroblasts (Ninomiya et al., 1993), to the cocultures of hippocampal neurons on $\beta$ APP-transfected $\mathrm{CHO}$ cells. Various concentrations of the antagonist peptide up to $10 \mu \mathrm{M}$ (Fig. $6 D$ ) produced no inhibition of the increased total neurite length/cell mediated by the surface-cxpressed $\beta$ APP. Taken together, these various experiments suggest
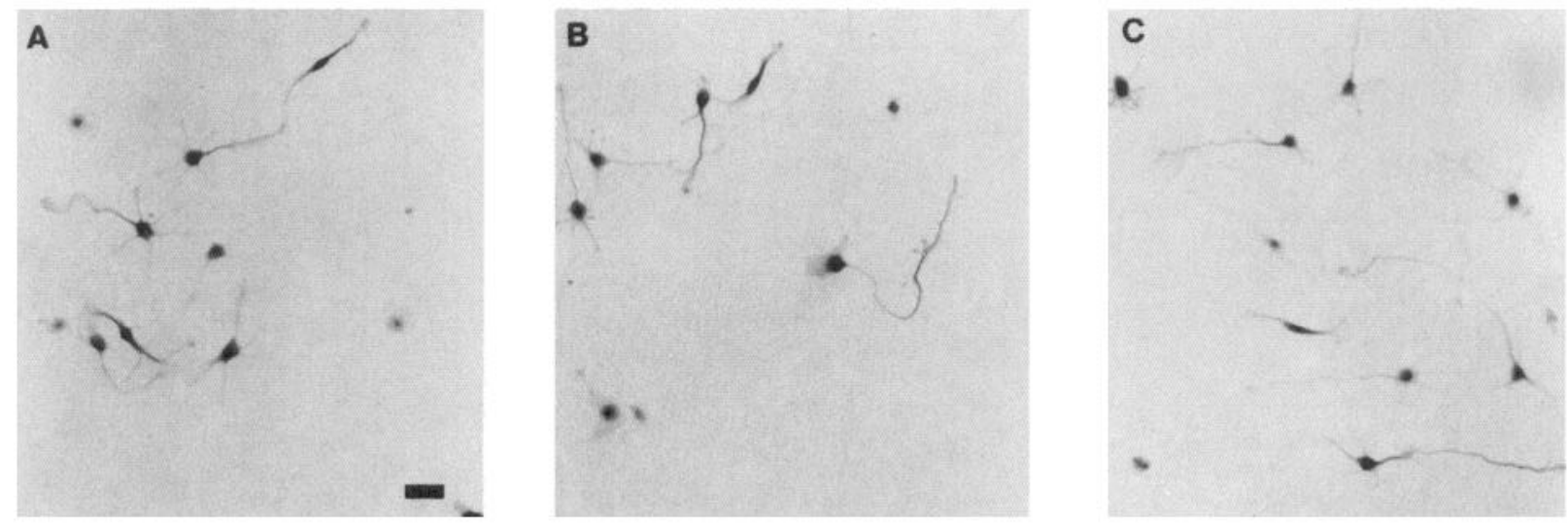

Figure 5. Conditioned media from $\beta \mathrm{APP}_{695^{-}}$and $\beta_{\mathrm{APP}} \mathrm{P}_{70^{-}}$transfected $\mathrm{CHO}$ cells do not enhance neurite outgrowth of hippocampal neurons compared to conditioned medium of untransfected CHO. Rat fetal day 19 hippocampal neurons grown on coverslips coated with poly-D-lysine were incubated in the conditioned medium from either untransfected $\mathrm{CHO}$ cells $(A)$ or $\beta \mathrm{APP}_{695}(B)$ or $\beta \mathrm{APP} \mathrm{P}_{770}(C)$ transfectants for $26-28 \mathrm{hr}$. Culture conditions and immunostaining with antiserum DJ were otherwise identical to those described in Figure 3 . Scale bar, $20 \mu \mathrm{m}$. 
A.

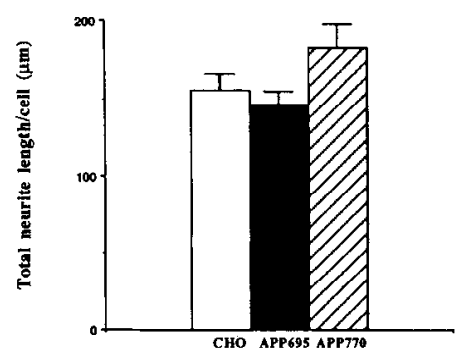

c.

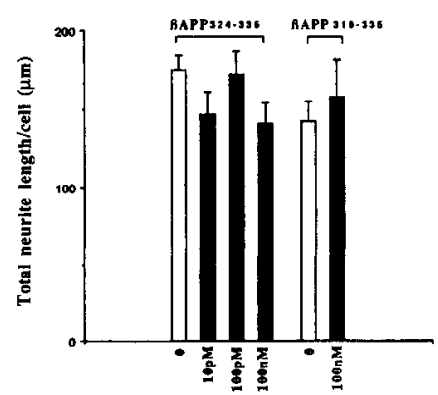

B.

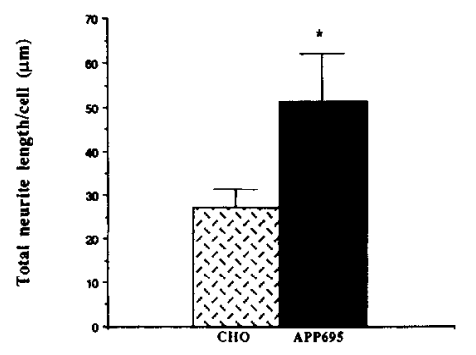

D.

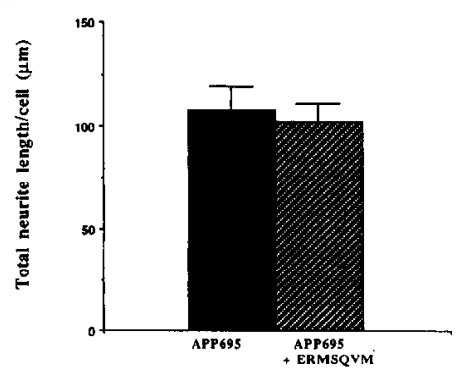

Figure 6. Quantitation of neurite length in various conditioned media. A, Quantitation of total neurite length/cell of hippocampal neurons grown as exemplified in Figure 5. $B$, As a positive control, PC12 cells cultured overnight in conditioned media from either untransfected $\mathrm{CHO}$ or $\beta \mathrm{APP}_{695}$ transfectants were analyzed identically. Data in $A$ and $B$ are expressed as a means \pm SEM from 70 counted neurons. Asterisks indicate significant differences $(p<0.05)$ relative to the effects of CHO conditioned medium. $C$, Supplementation of conditioned medium of untransfected CHO cells with peptides containing a growth-promoting sequence (RERMS) from secreted APP does not increase neurite outgrowth from hippocampal neurons. Rat fetal day 19 hippocampal neurons were cultured on poly-D-lysine coated coverslips in overnight conditioned medium from CHO cells (bar 1

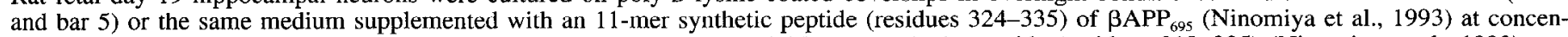
trations of $10 \mathrm{pM}$ (bar 2), $100 \mathrm{pm}$ (bar 3), or $100 \mathrm{nM}$ (bar 4). A related 17-mer synthetic peptide (residues 319-335) (Ninomiya et al., 1993) was added at a concentration of $100 \mathrm{nM}$ (bar 6$)$. After $26-28 \mathrm{hr}$, total neurite length/cell was measured and expressed as means \pm SEM $(n>50$ neurons counted). Both batches of peptides had been shown to be trophically active on fibroblasts and neuroblastoma cells (T. Saitoh, personal communication). $D$, A peptide which antagonizes the tropic effects of secreted $\mathrm{APP}_{\mathrm{s}}$ does not affect neurite outgrowth mediated by cell-surface $\beta \mathrm{APP}_{695}$. Peptide ERMSQVM $(10 \mu \mathrm{M})$ (Ninomiya et al., 1993) was added to the medium of rat hippocampal neurons cultured on $\beta$ APP ${ }_{695}$-transfected $\mathrm{CHO}$ cells. Total neurite length/cell in the absence and the presence of the antagonist peptide was quantitated in three independent experiments (means \pm SEM from a total of 50 neurons).

that there are different regions and distinct mechanisms underlying the growth-promoting properties of secreted and surfaceexpressed $\beta A P P$.

Delineation of the region in cell-surface $\beta A P P$ which mediates the neurite outgrowth

To define which region of cell-surface $\beta A P P$ confers the observed effect on neurite extension, we conducted blocking experiments using antibodies to different sequences within $\beta A P P$. As diagrammed in Figure $1 A$, two antibodies, polyclonal antibody, B5 (to $\beta_{A P P}{ }_{519-666}$ ), and the monoclonal antibody, 5A3 (precise epitope unknown), recognize the mid-region of $\beta A P P$. Because the epitope in $\beta$ APP which is involved in the neurite promotion is unknown and because $\mathrm{B} 5$ can react with the human $\beta A P P$ molecules transfected into $\mathrm{CHO}$ cells but less well with rat $\beta$ APP on the surface of the neurons, we chose $B 5$ rather than $5 \mathrm{~A} 3$ in the blocking experiment. Addition to the culture medium of affinity-purified B5 antibodies completely inhibited the en- hanced neurite extension produced by growth on $\beta \mathrm{APP}_{695}$-transfected CHO cells (Fig. 7A). As a result, total neurite length/cell remained the same as that seen on control $\mathrm{CHO}$ cells in the absence of B5 (Fig. 7A). Affinity purified polyclonal antibody $\mathrm{B} 3$ (Citron et al., 1992) to the N-terminal region $\beta A P_{20-302}$ did not alter the neurite-promoting activity mediated by $\beta \mathrm{APP}_{695}$ (Fig. 7A). As a further control, a polyclonal antiserum (C7) to the $\beta$ APP cytoplasmic domain also had no effect on neurite outgrowth, as expected (Fig. $7 A$ ). These data suggest that the mid-region of the $\beta A P P$ ectodomain preceding the $A \beta$ sequence contains an epitope which mediates this function.

To confirm this apparent localization of the adhesion domain of surface-expressed $\beta$ APP, CHO cells were transfected with a construct in which $\beta_{A P P}$ is is deleted by restriction enzyme digestion with XhoI (position 380) and BglII (position 666), yielding a protein lacking the entire B5 epitope (see Fig. 1A). As shown in Figure $7 B$, when this $\beta A P_{770}$ del transfectant was used as a substrate for the growth of hippocampal neurons, it pre- 


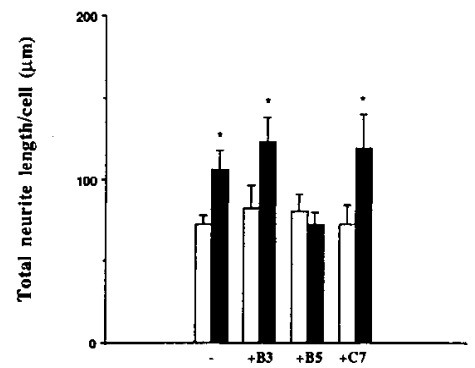

B.

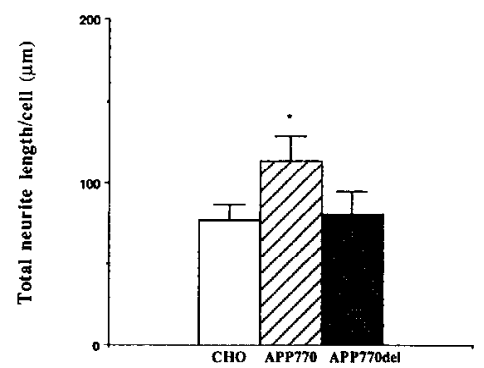

Figure 7. The carboxyl terminal portion of the $\beta$ APP ectodomain mediates the function of cell-surface $\beta$ APP in promoting neurite outgrowth. $A$, Rat fetal day 19 hippocampal neurons were cultured on monolayers of untransfected (open bars) or $\beta A P P_{695}$-transfected (solid bars) CHO cells. In parallel, three different polyclonal antibodies were added at the initial time of plating at concentrations of equivalent antibody activity (1.5 $\mu \mathrm{g}$ of B3 per $\mathrm{ml}, 2.4 \mu \mathrm{g}$ of B5 per $\mathrm{ml}$, or $1.8 \mu \mathrm{g}$ of $\mathrm{C} 7$ per $\mathrm{ml}$ ). After culturing for $26-28 \mathrm{hr}$, the cultures were fixed and stained with the DJ antiserum. Total neurite length/cell was measured and expressed as mean $\pm \operatorname{SEM}(n>70$ neurons counted). $B$, Hippocampal neurons were plated and grown on monolayers of untransfected $\mathrm{CHO}$ cells, or on $\beta A \mathrm{PP}_{770}$ or $\beta \mathrm{APP}{ }_{770}$ del transfectants. After $26-28 \mathrm{hr}$, neurons were fixed, stained and measured as in $A$.

vented the enhancement of neurite extension observed in neurons grown on wild-type $\beta_{A P P_{70}}$ transfectants. Because this result is consistent with the specific blocking effect of the B5 antibodies, our data strongly suggest that the activity of B5 is specific and that the sequence mediating the functional activity demonstrated in this study is located between amino acids 380 and 666 of $\beta A P P_{770}$, most likely between residues 519 and 666 (the $\mathrm{B} 5$ region), which is distinct from the growth promoting region defined in $\mathrm{APP}_{\mathrm{s}}$ (Ninomiya et al,, 1993).

\section{Discussion}

Following the initial cloning of $\beta$ APP, the observations that neurons express particularly high levels of the precursor (Goldgaber et al., 1987; Tanzi et al., 1987; Neve et al., 1988; Hung et al., 1992) and that some molecules appear to be localized to the cell surface in vivo (Shivers et al., 1988) suggested that the protein might mediate cell-cell contact in the CNS. Subsequent studies showed that $\beta$ APP is conveyed to nerve terminals by fast axonal transport (Koo et al., 1990), that developing neurons undergo increased expression of $\beta$ APP which is preferentially localized to the growth cones of their processes (Ferreira et al., 1993), and that immature neurons metabolize very little of their abundant $\beta A P P$ into the cleaved, secreted derivative $\left(\mathrm{APP}_{\mathrm{s}}\right.$ ) (Hung et al., 1992). Taken together, these findings point to a possible role for full-length $\beta$ APP in neurite outgrowth via a specific cellcell adhesion function, but no direct studies of the function of cell surface-inserted $\beta$ APP have been reported. Here, we demonstrate that fetal hippocampal neurons respond specifically to BAPP expressed at the surface of cells with which they come into contact by undergoing enhanced attachment and neurite outgrowth, and that this response is distinct from those previously described for secreted $\mathrm{APP}_{s}$

We used a system in which developing neurons are grown on transfected non-neural cells expressing various isoforms of $\beta A P P$ in order to distinguish the functional properties of cell surface $\beta$ APP from those of soluble $\mathrm{APP}_{\mathrm{s}}$ and the $A \beta$ and $\mathrm{p} 3$ peptides, all of which are released continuously by neuronal and glial cells in the CNS. This paradigm enables one to quantitate the amount of holoprotein inserted at the plasma membrane and to use recombinant techniques to delete or enhance putative functional domains of the precursor in order to establish their biological activities. We found that CHO cells stably overexpressing each of the three major isoforms of full-length $\beta A P P$ produced a significant increase in initial neuronal attachment. This enhanced adhesion could be blocked by the BAPP ectodomain antibody, B5, when the neurons were grown on either

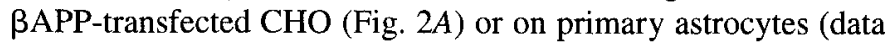
not shown). Therefore, the enhanced number of neurons seen at 26-28 hr (Fig. 2) resulted from increased cell adhesion. Furthermore, the degree of enhanced cell-cell interaction paralleled the amount of surface-expressed $\beta A P P$ in both $\beta_{A P P_{695}}$ and $\beta A P P_{770}$ clones (compare Figs. $1 D, 2 B, C$ ). The adhesive characleristics of $\mathrm{APP}_{\mathrm{s}}$ were demonstrated previously in studies examining PC12 cells attached to $\mathrm{APP}_{\mathrm{s}}$-coated dishes (Schubert et al., 1989). Therefore, $\beta$ APP may function in both specific cellcell and cell-matrix interactions in vivo. Like other examples of cell-surface expressed adhesion molecules which promote neuronal differentiation in the nervous system, for example, NCAM and F3/F11 (Doherty et al., 1990; Gennarini et al., 1991), cellsurface $\beta A P P$ was also found to enhance neurite outgrowth in the rat fetal hippocampal neurons by increasing the mean neurite length, but it did not affect the mean number of primary neurites per cell (Figs. 3, 4).

Trophic activities of either $\mathrm{APP}_{s}$ or $\mathrm{A} \beta$ on fibroblasts (Saitoh et al., 1989) and neurons (Schubert et al., 1989; Whitson et al., 1989; Yankner et al., 1990; Araki et al., 1991; Chen and Yankner, 1991; LeBlanc et al., 1992; Milward et al., 1992) have been demonstrated in previous studies. In this study, several experiments showed that no enhanced neurite promotion could be detected in the conditioned media of the BAPP-transfected cells, probably because the secreted derivatives (particularly $\mathrm{APP}_{\mathrm{s}}$ ) produced endogenously by the $\mathrm{CHO}$ cells saturated the neurons. Instead, the consistent and statistically significant increase in neurite outgrowth observed in our cocultures can be attributed to the increased surface expression of BAPP in the transfected cells on the basis of several findings. First, no difference was seen in the neurite outgrowth of hippocampal neurons grown on poly-D-lysine in transfectant conditioned medium markedly enriched in the secreted $\beta$ APP derivatives compared to that in plain CHO medium (Figs. 5, 6A). Second, neurite outgrowth on untransfected $\mathrm{CHO}$ cells supplemented with transfectant-conditioned medium rich in $\mathrm{APP}_{\mathrm{s}}$ also produced no ncurite cnhanccment after $24 \mathrm{hr}$ (Fig. 4B), excluding the possibility that $\mathrm{APP}_{\mathrm{s}}$ itself or an interaction between $\mathrm{APP}_{s}$ and extracellular matrix molecules played a role in our response. Considering the basal 
level of endogenous $\mathrm{APP}_{\mathrm{s}}$ produced by untransfected $\mathrm{CHO}$ cells that can saturate the neurons, the lack of response to the additional transfectant-derived $\mathrm{APP}_{\mathrm{s}}$ was seen whether the neurons were grown on a stronger growth-promoting substrate, poly-Dlysine or a weaker substrate, $\mathrm{CHO}$ cells. Third, the trophic effect of $\mathrm{APP}_{\mathrm{s}}$ has been localized to a five residue sequence, RERMS (Ninomiya et al., 1993). However, when our hippocampal neurons were treated with CHO medium supplemented with two different active peptides (T. Saitoh, personal communication) containing this sequence, no increase in neurite length/cell was obtained (Fig. $6 C^{\prime}$ ). Fourth, a partially overlapping $\beta$ APP peptide shown to antagonize the trophic effect of APP (Ninomiya et al., 1993) did not block the ncuritc promoting activity of the BAPPtransfectants we used as a substrate for growth of hippocampal neurons (Fig. $6 D$ ). Therefore, all of our data strongly suggest that the increased neurite outgrowth appearing in the cocultures is caused by surface-expressed $\beta$ APP rather than $\mathrm{APP}_{s} \mathrm{~A} \beta$ or other secreted derivatives. Although we believe it is unlikely, we can not completely exclude the possibility that $\beta$ APP overexpression could influence the $\mathrm{CHO}$ to secondarily produce a different neurite-promoting molecule. Because very small amounts of $\mathrm{APP}_{\mathrm{s}}$ are secreted by immature astrocytes, microglia and neurons in vitro (Haass et al., 1991; Hung et al., 1992), our results lead us to hypothesize that surface-inserted $\beta$ APP may play a more important role than $\mathrm{APP}_{\mathrm{s}}$ in the initial development and differentiation of CNS neurons.

Protease nexin I is a glial-derived serine protease inhibitor that has been shown to stimulate neurite outgrowth in cultured neuroblastoma cells and primary neurons (Gloor et al., 1986; Zurn et al., 1988). Although protease nexin II (the secreted form of the KPI-containing $\beta_{A P P_{751770}}$ isoforms) has been proposed to have similar functions as protease nexin $I$, no enhancement of neurite outgrowth was observed when secreted $\mathrm{APP}_{s}$ derived from $\beta \mathrm{APP}_{751}$ transfectants was compared to that from $\beta \mathrm{APP}_{695}$ transfectants (Araki et al., 1991; Milward et al., 1992). However, the surface-expressed forms of these molecules examined here produced a clear difference in growth promotion of axons and minor processes during $24 \mathrm{hr}$ culturing of hippocampal neurons (Figs. 3, 4; Table 1). For example, although one of our $\beta_{A P P}{ }_{695}$ CHO clones $\left(\beta \mathrm{APP}_{695}\right)$ expressed a substantially higher level of $\beta A P P$ on the cell surface than a $\beta A P P_{770}$ clone did, their ability to promote neurite outgrowth was approximately the same (Table 1). Likewise, clone $\beta \mathrm{APP}_{695} \mathrm{~B} 4$ had approximately equivalent surface expression of the precursor as clones $\beta A P P_{770}$ and $\beta A P P_{75} D 4$, yet it displayed less neurite-promoting activity. Furthermore, two different antibodies to the KPI domain partially blocked the neurite promoting activity of $\beta A \mathrm{AP}_{770}$, bringing it down to the level mediated by clone $\beta A P P_{695} \mathrm{~B} 4$, which has a closely similar number of cell-surface $\beta$ APP molecules (Table 1). However, the fact that clone $\mathrm{APP}_{770} \mathrm{del}$, which contains the KPI motif but not the mid-region of the ectodomain, showed no neurite promoting activity (Fig. $7 B$ ) suggests that the protease inhibitory domain by itself is not sufficient to account for the effect. of $\beta \mathrm{APP}_{751770}$ on neurite outgrowth in our system. Thus, we hypothesize that there are two neurite-promoting regions which work cooperatively in surface-expressed $\beta A P P$, one shared among all isoforms and the other localized to the Kunitz protease inhibitory motif.

The approximate region of surface $\beta$ APP which is apparently involved in the cell-cell adhesion and neurite outgrowth we observed was identified by antibody blocking experiments and analysis of deletion constructs (Fig. 7). Although the region de- fined to date, residues $380-666$ of $\beta A P P_{770}$, contains the RERMS sequence, the cell-cell interactions occurring in our system are not mediated through the latter motif (Fig. 6). However, the region does contain the 18 residue of exon 15 which is known to be absent in one alternatively spliced form of $\beta$ APP, L-APP (König et al., 1992). The expression of the L-APP form is high in nonadherent and low in adherent leukocytes suggesting that this region could be important for the function of adhesion in neurons, as well.

Our data further suggest that there are distinct epitopes underlying the growth promoting effects of surface-expressed $\beta A P P$ and $\mathrm{APP}_{s}$, although their extracellular domains have largcly the samc primary structure. This concept is supported by the recent finding of Small et al. that the region comprising residues 96-110 of $\mathrm{APP}_{s}$ bound heparan sulfate proteoglycan (HSPG) and that this interaction, not the presence of $\mathrm{APP}_{\mathrm{s}}$ alone, promoted neurite outgrowth in hippocampal neurons (Small et al., 1994). Their data also suggested that the type of HSPG was critical for the neurite outgrowth-promoting effect of $\mathrm{APP}_{s}$. Therefore, the lack of neuronal response to the increased amount of $\mathrm{APP}_{\mathrm{s}}$ in our culture system could relate in part to the absence of the correct type of HSPG. It is also of interest that the B5reactive region of secreted APP , has been shown to have a calcium-lowering activity that mediates neuroprotection and neurite outgrowth in cultured hippocampal neurons (Mattson et al., 1993; Mattson, 1994). It is therefore possible that the same signal transduction mechanism (i.e., lowering of intraneuronal calcium levels) could mediate the neurite promotion conferred by surface-expressed $\beta$ APP in our experiments. It will now be interesting to determine whether the 18 amino acids of exon 15 or another motif in the B5-reactive region is the determinant for the neurite promotion mediated by cell surface $\beta$ APP. Moreover, the intriguing question of whether there are two different receptors for the distinct functional activities of $\beta A P P$ and $\mathrm{APP}_{\mathrm{s}}$ or one common receptor which binds surface $\beta A P P$ and $\mathrm{APP}_{5}$ differently now needs to be addressed.

\section{References}

Araki W, Kitaguchi N, Tokushima Y, Ishii K, Aratake H, Shimohama S, Nakamura S, Kimura J (1991) Trophic effect of $\beta$-amyloid precursor protein on cerebral cortical neurons in culture. Biochem Biophys Res Commun 181:265-271.

Bartlett WP, Banker GA (1984) Electron microscopic studies of axonal and dendritic development by hippocampal neurons in culture. I: Cells which develop without intercellular contacts. J Neurosci 4:1944-1953.

Bottenstein JE, Sato GH (1979) Growth of a rat neuroblastoma cell line in serum-free supplemented medium. Proc Natl Acad Sci USA 76:514-517.

Breen KC, Bruce M, Anderton BH (1991) Beta amyloid precursor protein mediates neuronal cell-cell and cell-surface adhesion. J Neurosei Res 28:90-100.

Chen M, Yankner BA (1991) An antibody to $\beta$-amyloid and the amyloid precursor protein inhibits cell-substratum adhesion in many mammalian cell types. Neurosci Lett 125:223-226.

Citron M, Oltersdorf T, Haass C, McConlogue L, Hung AY, Seubert P, Vigo-Pelfrey C, LIeberburg I, Selkoe DJ (1992) Mutation of the $\beta$-amyloid precursor protein in familial Alzheimer's disease increases $\beta$-protein production. Nature 360:672-674.

Cole GM, Huynh TV, Saitoh T (1989) Evidence for lysosomal processing of beta-amyloid precursor in cultured cells. Neurochem Res 14:933-939.

Doherty P, Fruns M, Seaton P, Dickson G, Barton CH, Sears TA, Walsh FS (1990) A threshold effect of the major isoforms of NCAM on neurite outgrowth. Nature 343:464-466.

Esch FS, Keim PS, Beattie EC, Blacher RW, Culwcll AR, Oltcrsdorf T, McClure D, Ward PJ (1990) Cleavage of amyloid $\beta$-peptide 
during constitutive processing of its precursor. Science 248:11221124.

Ferreira A, Niclas J, Vale RD, Bank G, Kosik K (1992) Suppression of kinesin expression in cultured hippocampal neurons using antisense oligonucleotides. J Cell Biol 117:595-606.

Ferreira A, Caceres A, Kosik K (1993) Intraneuronal compartments of the amyloid precursor protein. J Neurosci 13:3112-3123.

Fukuchi K, Deeb SS, Kamino K, Ogburn CE, Snow AD, Sekiguchi RT, Wight TN, Piussan H, Martin GM (1992) Increased expression of $\beta$-amyloid protein precursor and microtubule-associated protein $t$ during the differentiation of murine embryonal carcinoma cells. J Neurochem 58:1863-1873.

Gennarini G, Durbec P, Boned A, Rougon G, Goridis C (1991) Transfected F3/F11 neuronal cell surface protein mediates intercellular adhesion and promotes neurite outgrowth. Neuron 6:595-606.

Glenner GG, Wong CW (1984) Alzheimer's disease: initial report of the purification and characterization of a novel cerebrovascular amyloid protein. Biochem Biophys Res Commun 120:885-890.

Gloor S, Odink K, Guenther J, Nick H, Monard D (1986) A gliaderived neurite promoting factor with protease inhibitory activity belongs to the protease nexins. Cell 47:687-693.

Golde TE, Estus S, Younkin LH, Selkoe DJ, Younkin SG (1992) Processing of the amyloid protein precursor to potentially amyloidogenic derivatives. Science 255:728-730.

Goldgaber D, Lerman MI, McBridge OW, Gajdusek DC (1987) Characterization and chromosomal localization of a cDNA encoding brain amyloid of Alzheimer's disease. Science 235:877-880.

Goslin K, Banker GA (1991) Rat hippocampal neurons in low density culture. Cambridge, MA: MIT Press.

Haass C, Hung AY, Selkoe DJ (1991) Processing of $\beta$-amyloid precursor protein in microglia and astrocytes favors a localization in internal vesicles over constitutive secretion. J Neurosci 11:37833793.

Haass C, Koo EH, Mellon A, Hung AY, Selkoe DJ (1992a) Targeting of cell-surface $\beta$-amyloid precursor protein to lysosomes: alternative processing into amyloid-bearing fragments. Nature 357:500-503.

Haass C, Schlossmacher MG, Hung AY, Vigo-Pelfrey C, Mellon A, Ostaszewski BL, Lieberburg I, Koo EH, Schenk D, Teplow DB, Selkoe DJ (1992b) Amyloid $\beta$-peptide is produced by cultured cells during normal metabolism. Nature 359:322-325.

Hung AY, Koo EH, Haass C, Selkoe DJ (1992) Increased expression of $\beta$-amyloid precursor protein during neuronal differentiation is not accompanied by secretory cleavage. Proc Natl Acad Sci USA 89: 9439-9443.

Kang J, Lemaire H, Unterbeck A, Salbaum JM, Masters CL, Grzeschik K. Multhaup G, Beyreuther K, Muller-Hill B (1987) The precursor of Alzheimer's disease amyloid A4 protein resembles a cell-surface receptor. Nature 325:733-736.

Kitaguchi N, Takahashi Y, Tokushima Y, Shiojiri S, Ito H (1988) Novel precursor of Alzheimer's disease amyloid protein shows protease inhibitory activity. Nature 331:530-532.

König G, Monning U, Czech C, Prior R, Banati R, Schreiter-Gasser U, Bauer J, Masters CL, Beyreuther K (1992) Identification and differential expression of a novel alternative splice isoform of the $\beta A 4$ amyloid precursor protein (APP) mRNA in leukocytes and brain microglial cells. J Biol Chem 267:10840-10809.

Koo EH, Sisodia SS, Archer DA, Martin LJ, Weidemann A, Beyreuther K, Masters CL, Fischer P, Price DL (1990) Precursor of amyloid protein in Alzheimer's disease undergoes fast anterograde axonal transport. Proc Natl Acad Sci USA 87:1561-1565.

Koo EH, Haass C, Selkoe DJ (1993) Familial Alzheimer's disease mutation within transmembrane amyloid precursor protein (APP) sequence results in altered cell surface processing. Neurol $\Lambda$ bstr 43: 422.

Kosik KS, Orecchio LD, Binder L, Trojanowski JQ, Lee VM-Y, Lee G (1988) Epitopes that span the tau molecule are shared with paired helical filaments. Neuron 1:817-825.

LeBlanc AC, Kovacs DM, Chen HY, Villare F, Tykocinski M, AutilioGambetti L, Gambetti P (1992) Role of amyloid precursor protein (APP): study with antisense transfection of human neuroblastoma cells. J Neurosci Res 31:635-645.

Loffler J, Huber G (1992) $\beta$-Amyloid precursor protein isoforms in various rat brain regions and during brain development. J Neurochem 59:1316-1324.

Masliah E, Mallory M, Ge N, Saitoh T (1992) Amyloid precursor protein is localized in growing neurites of neonatal rat brain. Brain Res 593:323-328.

Mattson MP (1994) Secreted forms of $\beta$-amyloid precursor protein modulate dendrite outgrowth and calcium responses to glutamate in cultured embryonic hippocampal neurons. J Neurobiol 25:439_ 450.

Mattson MP, Cheng B, Culwell AR, Esch FS, Lieberburg I, Rydel RE (1993) Evidence for excitoprotective and intraneuronal calcium-regulating roles for secreted forms of the $\beta$-amyloid precursor protein. Neuron 10:243-254.

Milward EA, Papadopoulos R, Fuller SJ, Moir RD, Small D, Beyreuther K, Masters CL (1992) The amyloid protein precirsor of Alzheimer's disease is a mediator of the effects of nerve growth factor on neurite outgrowth. Neuron 9:129-137.

Narindrasorasak S, Lowery D, Gonzalez-DeWhitt P, Poorman RA, Greenberg B, Kisilevsky R (1991) High affinity interactions between the Alzheimer's beta-amyloid precursor proteins and the basement membrane form of heparan sulfate proteoglycan. J Biol Chem 266: $12878-12883$

Neve RL, Finch EA, Dawes LR (1988) Expression of the Alzheimer amyloid precursor gene transcripts in the human brain. Neuron $1: 669-677$

Ninomiya H, Roch J, Sundsmo MP, Otero DAC, Saitoh T (1993) Amino acid sequence RERMS represents the active domain of amyloid $\beta / A 4$ protein precursor that promotes fibroblast growth J Cell Biol 267:2214-2221.

Oltersdorf T, Ward PJ, Henriksson T, Beattie EC, Neve R, Lieberburg I, Fritz LC (1990) The Alzheimer amyloid precursor protein. Identification of a stable intermediate in the biosynthetic/degradative pathway. J Biol Chem 265:4492-4497.

Ponte P, Gonzalez-DeWhitt P, Schilling J, Miller J, Hsu D, Breenberg B, Davis K, Wallace W, Lieberburg I, Fuller F, Cordell B (1988) A new A4 amyloid mRNA contains a domain homologous to serine proteinase inhibitors. Nature 331:525-527.

Saitoh T, Sunsdmo M, Roch J-M, Kimura N, Cole G, Schubert D, Oltersdorf T, Schenk DB (1989) Secreted form of amyloid $\beta$ protein precursor is involved in the growth regulation of fibroblasts. Cell 58: 615-622.

Schubert D, Jin L-W, Saitoh T, Cole G (1989) The regulation of amyloid $\beta$ protein precursor secretion and its modulatory role in cell adhesion. Neuron 3:689-694.

Seubert P, Vigo-Pelfrey C, Esch F, Lee M, Dovey H, Davis D, Sinha S, Schlossmacher MG, Whaley J, Swindlehurst C, McCormack R, Wolfert R, Selkoe DJ, Lieberburg I, Schenk D (1992) Isolation and quantitation of soluble Alzheimer's $\beta$-peptide from biological fluids. Nature 359:325-327.

Shioi J, Anderson JP, Ripellino JA, Robakis NK (1992) Chondroitin sulfate proteoglycan form of the Alzheimer's $\beta$-amyloid precursor. $\mathbf{J}$ Biol Chem 267:13819-13822.

Shivers BD, Hilbich C, Multhaup G, Salbaum M, Beyreuther K, Seeburg PH (1988) Alzheimer's disease amyloidogenic glycoprotein: expression pattern in rat brain suggests a role in cell contact. EMBO J 7:1365-1370.

Sisodia SS, Koo EH, Beyreuther K, Unterbeck A, Price DL (1990) Evidence that $\beta$-amyloid protein in Alzheimer's disease is not derived by normal processing. Science 248:492-495.

Small DH, Nurcombe V, Reed G, Clarris H, Moir R, Beyreuther K, Masters CL (1994) A heparin-binding domain in the amyloid protein precursor of Alzheimer's disease is involved in the regulation of neurite outgrowth. J Neurosci 14:2117-2127.

Tanzi RE, Gusella JF, Watkins PC, Bruns GAB, St George-Hyslop PH, Van Keuren ML, Patterson D, Pagan S, Kurnit DM, Neve RL (1987) Amyloid $\beta$-protein gene: cDNA, mRNA distribution, and genctic linkage near the Alzheimer locus. Science 235:880-884.

Tanzi RE, McClatchey AI, Lamperti ED, Villa-Komaroff L, Gusella JF, Neve RL (1988) Protease inhibitor domain encoded by an amyloid protein precursor mRNA associated with Alzheimer's disease. Nature 331:528-532.

Wang R, Meschia JF, Cotter RJ, Sisodia SS (1991) Secretion of the $\beta / A 4$ amyloid precursor protein. Identification of a cleavage site in cultured mammalian cells. J Biol Chem 266:16960-16964.

Weidemann A, Konig G, Bunke D, Fischer P, Masters CL, Beyreuther $\mathrm{K}$ (1989) Identification, biogenesis and localization of precursors of Alzheimer's disease A4 amyloid protein. Cell 57:115-126.

Whitson IS, Selkoe DJ, Cotman CW (1989) Amyloid $\beta$ protein en- 
hances the survival of hippocampal neurons in vitro. Science 243: $1488-1490$.

Yankner BA, Duffy LK, Kirschner DA (1990) Neurotrophic and neurotoxic effects of amyloid $\beta$ protein: reversal of tachykinin neuropeptides. Science 250:279-282.
Zurn AD, Nick H, Monard D (1988) A glia-derived nexin promotes neurite outgrowth in cultured chick sympathetic neurons. Dev Neurosci 10:17-24. 